\title{
Nexus between Women Labour Migrants, Protection and Policy Implementation: A Study on National Labour Migration Policy Implementation in Sri Lanka
}

\section{K.D. Dushmanthi Silva ${ }^{1}$}

\section{Abstract}

Female labour migration has been recognized as the second largest foreign exchange source of earning where women who are mostly unskilled, low educated or non-educated are part of it. Sri Lanka, being part of labour outsourcing, has introduced the National Labour Migration Policy to protect the migrant workers and their families. Though the policy is largely genderneutral, it addresses specific issues related to women migrant workers who are in the domestic workers' category. Despite the policy being implemented, there is a need to understand why women are still in a vulnerable situation. Thus this study intends to explore the ways in which the National Labour Migration Policy in Sri Lanka ensures the protection of women labour migrants. Qualitative research design and case study strategy were employed in this study. Relevant data and evidence were gathered through interviews with bureaucrats from Sri Lanka Bureau of Foreign Employment, returnee migrant women, families of returnee migrant women, local manpower agencies and sub-agents, who are engaged in this migration process. The study argues that women are not protected when there is a negative attitude of street-level bureaucrats towards the target group. This largely ignores the rights of women labour migrants. Moreover, policy action taken irrespectively to the needs and the condition of the women in the society hence policy may not successfully achieve its goals.
${ }^{1}$ Department of Sociology, University of Ruhuna, Sri Lanka dushmanthi.silva@gma il.com

Keywords: implementation, migration, policy, street level bureaucrats, women labour 


\section{INTRODUCTION}

Women labour migration from Sri Lanka to overseas countries including the Middle East is one of the main sources of foreign exchange in the country. The Sri Lankan government is directly involved in supplying this labour force. It has been a popular way of earning money for unskilled labour, especially for unskilled women. The opportunities were blooming up since introducing the open economy in Sri Lanka in 1978. Middle East countries remain the main destination of Sri Lankan migrant employees and those are mainly Saudi Arabia, UAE, Kuwait and Qatar. By 2017, 79 \% of the total migrant employees were recruited by these four countries (SLBFE, 2017). Though the statistics show that female migrant number has been decreasedsince2013, still a large number of female migrants are working in Middle East countries (SLBFE, 2017). Further, these statistics show the highest number of complaints was received from the female migrants. In the year 2017, 4617total number complaints received from migrant workers only and the majority of them were from the female labour force. These complaints are mainly for breach of contract, physical or sexual harassments, non-payment of salary. However, the statistics do not show the number of complaints received during the pre-departure stage. Previous studies revealed that these domestic migrant workers experience the condition of slaves in confined private homes. Most of them were highly exploited, sexually abused or harassed by their employers (Hettige 2012; Hettiarachci 2007; Wickramasekra2013, Pinnawala 1997).

Most of the problems which women migrant workers face are originated from the irregularities at the predeparture stage. At the pre-departure stage, local manpower agencies and community networks directly influence women to take the decision to migrate. Ukwatta (2010) and Pinnawala (2012) also found that women rely on their relatives or local private agencies or returnee migrants to get information and get job opportunities. But there is no such study on how far the government policy ensures the protection of migrant women workers at their predeparture. Therefore it is important to study the role of the government agency in order to protect women labour migrants.

In 2009, the Sri Lankan government adopted the National Migration Policy which commits to the "governance, protection and empowerment and development of migrant workers" (National Labor Migration Policy, 2009). Sri Lanka Bureau of Foreign Employment (SLBFE), set up under Act 21, 1985 (also amended in 1994 and 2009) is the main legal body which governs this policy. The SLBFE plays a major role in providing information to people who seek jobs in foreign lands especially in the low skilled category. One of the main objectives of the SLBFE is to convey correct information 
on migration procedure and on recruitment agencies.

The SLBFE is implementing their action plans for promoting and supplying more skilled workers to the foreign labour market. This includes language training, training to meet global needs, maximizing remittance benefits and incentives (NLMP, 2009). The SLBFE maintains a foreign employment agency where people can get employment opportunities. SLBFE established 12 regional offices and has island-wide awareness programs. Moreover, they have introduced a 24hour hotline facility to get information and record complaints. Local private manpower agencies dedicated to foreign employment needs to be registered at the SLBFE. Nearly 1000 local manpower agencies are registered at the SLBFE by the year 2017. These local manpower agencies take assistance from sub-agents or from local community people. Thus, besides government initiatives, many local manpower agencies and community networks trigger the migration process. Though the National Migration Policy is genderneutral, it has given some special attention to female migrants too. The government initiated several actions towards the protection of female migrant workers such as increasing the age limit of domestic migrants, giving training prior to migration. These were taken after considering the problems faced by female migrant workers. However, this study pinpoints why women migrant workers are still vulnerable through the National Labour Migration Policy aims to protect migrant workers. To explore the research problem, this study aims to identify how far the government agency performs its role to ensure the protection of female migrants at the whole migration process. At this end, this chapter focuses on two variables i.e., to what extent the migrant women are being protected and the independent variable what role do government play in order to implement the policy. Further to this study has narrowed down the role of government in focusing the street-level bureaucrats as they are the key persons in policy implementation. In this light, this paper discusses the ways in which the National Migration Policy ensures the protection of female migrants and the obstacles for its successful implementation.

\section{POLICY IMPLEMENTATION}

Theoretically, policy implementation has been differently defined by many scholars. Policy implementation brings decisions into action. The policy is no longer effective until it is being practiced and reaches its aims and objectives. In a precise way, it can be explained as "translating a policy decision into action" (Howelt et al., 2009, p. 160).

Scholars such as Van Meter and Van Horn (1975), Mazmanian and Sabatier (1983), and their followers, claim that policy decisions are taken at the top 
level of the government and policy implementation is an action against set objectives, and how far they have been achieved. Van Meter and Van Horn (1975) explained "Policy Implementation" as a set of actions formed by policy decisions for public and private individuals to achieve policy objectives. They define policy implementation as that which "encompasses those actions by public and private individuals (or groups) that are directed at the achievement of objectives set forth in prior policy decisions." (Meter \& Horn, 1975,p. 447-448). Mazmanian and Sabatier (1983) have explained this in a more specific way; according to them, policy implementation encompasses events and activities that identify problem(s) to be addressed, anticipate objective(s) to be achieved, and means of achieving those policy directives to be issued in the form of executive orders or court decisions (Mazmanian\& Sabatier, 1980; 540-541). O'Toole (1995, cited in Hill \& Hupe, 2014,p. 8) defines policy implementation as 'what develops between the establishment of an apparent intention on the part of the government to do something or stop doing something, and the ultimate impact in the world of action'. Therefore, policy implementation refers to the connection between the governments' intentions and actual results.

Apart from the explanation on policy implementation as an action taken to reach the set goals of government bodies, studies have focused on government and non-government actors' role in policy implementation. Different bureaucratic agencies at different levels of government are usually involved in this stage and each has different roles, interests, and traditions, that affect the implementation process and its' outcomes (Howeltt, et al., 2009,p. 160). Eugene Bardach (1977) sees implementation as a continuation of the political game from the policy adoption stage, partly with other actors and other relations among actors. Further, it explains how various actors apply the implementation process to pursue their own interests (Winter, 2006, p. 152-153).

The top-down approach in policy implementation highlighted lack of policy objectives as a failure of policy implementation and its highlighted the importance of having unambiguous policy goals and objectives for effective policy implementation. On the other hand, the bottom-up approach focused on the behaviour of bureaucrats in the policy implementation process (Lipsky, 1980; Winter, 2006). Lipsky (1980) in his masterpiece on "StreetLevel Bureaucracy," explicitly states that street-level bureaucrats are professionals and semi-professionals found in different occupations. According to Lipsky (1980), streetlevel bureaucrats face problems in an organization where they cannot control their work; so they have to make their own choices to solve these problems. Lipsky (1980) termed this as 
a 'coping strategy,' which is also called 'discretion.' Also, managers and streetlevel bureaucrats follow their different interests and they make their own rules or reshape rules, and ultimately, rules or agency goals can be controlled. Finally, the policy becomes what street-level bureaucrats do (Lipsky, 1980, p. 18). Further, Winter (2012) explains those bureaucrats work in situations characterized by many demands and limited resources, and they control clients and modify policy goals and client perceptions (Winter, 2012, p. 10). Hence, their role in policy implementation is crucial in policy outcomes. Therefore, the capacity of street-level bureaucrats to resist organizational directives is an important factor that should be discussed here. Based on these theoretical analyses, this study focuses on how the role of street-level bureaucrats influences policy effectiveness.

Following the bottom-up approach in policy implementation, this study analyses the role of street-level bureaucrats in implementing the National Labour Migration Policy in Sri Lanka. The literature on women labour migration has largely unfolded the stories of harassments which women are facing in host countries as well as their pre-departure stage. Sexual abuse, violence, salary discrimination, inhuman working conditions were identified as the problems faced by women migrants in host countries (Hetti-Arachchi, 2012, Mahanama \& Thennakoon, 2012).
Scholars in the field of migration have stated the absence of specific programmes that target returnee migrant workers to ensure their successful integration into the society they left behind. Primary health care needs of returnee migrant workers are minimal. In fact, mental and physical health care needs are identified, and necessary services including medical services, psychiatric services, and counselling are provided, yet, there is a need to include health issues into the reintegration process (Hettige, 2012).

Besides health issues, there are other social issues, mainly regarding the family of the migrant worker. If the mother migrates and leaves her children behind, there would be a lack of the proper process of socialization, which will also affect children in numerous ways; i.e. schooling, health, and physical and mental development (Ukwatta, 2010). This gives evidence on how migrant women are largely unprotected in Middle East countries through the National Migration Policy aims to protect women migrants. Hence the literature on women labour migration proves that there is a policy failure or non-implementing the policy in Sri Lanka. Moreover, the literature in bureaucracy in Sri Lanka mostly focuses on the bureaucratic system of the country, corruption and politicization of the system (Abeyratne, 2013; Warnapala, 2012; Jayasuriya, 2000; Navaratne-Bandara, 2013). Thus this study fills the gap in the existing literature of the field of street-level bureaucracy in the Sri 
Lanka country context especially in the field of women labour migration. Furthermore, this study raises some questions to explore and answer what role do the street-level bureaucrats play in-order to achieve the policy goals? which factors hinder their performance?. To answer the above questions this study examines the results with the theory of street-level bureaucracy and analyse the policy and practice.

\section{METHODOLOGY}

Qualitative research design helps to understand the particular situation or incident or the particular culture or community (Cresswell, 2014). Therefore, a qualitative research design is more appropriate in this study to analyse participants' points of view on policy effectiveness. This study relied on participants' views, in order to understand the policy performance. How the roles of bureaucrats' affect implementing of the Labour Migration Policy in Sri Lanka was examined here, and the research mainly discusses the situation on the basis of participants' experiences but is somewhat developed as a causal explanation. Employing the qualitative data collection methods this qualitative research has total sample 21 bureaucrats at the SLBFE, 12 returnee migrant women from Middle East countries from Omaragolla village in Kurunegala district, where a large number of migration population exists in Sri Lanka. Furthermore, 3 local manpower agencies and 2 sub-agents and were included in the sample which helped to cross-tabulate the data on policy implementation. Snowball sample method was adopted in order to select the returnee migrant worker sample with the help of key informants in the selected villages and purposive sampling method was used to get officials and the manpower agencies. Data were gathered mainly on in-depth interviews with female migrants and semi-structured interviews followed by the interview guideline were used to other stakeholders. Moreover focus group discussions were held to returnee migrants women on their experience at the workplace and pre-departure stage. Each focus group includes 5 returnee migrants women and discussion lasted for one hour. Furthermore, some data such as how the women migration has an impact on the family especially to husband and children were gathered through observations and secondary data was gathered through document review at the SLBFE. All interviews were recorded with prior approval of respondents and were transcribed based on the thematic method which helped to analyse the data.

\section{RESULTS AND DISCUSSION}

This study mainly discusses the role of bureaucrats in implementing the National Labour Migration Policy in Sri Lanka. It focuses on how the National Migration Policy ensures the protection of women migrants in the 
host country as well as the in-home country at their pre-departure stage. Policy implementation was measured by the indicators which were given the policy itself. There are three indicators mentioned in the policy. i.e, deliver comprehensive training, strengthening the existing law and regulating the recruitment system, mechanism to monitor and minimize abuses. Furthermore, analyzing how far the policy has been achieved these targets shows whether women have been protected or not protected and what are the limitation in policy implementation.

\section{IMPLICATION OF MIGRATION POLICY}

NATIONAL

The vision of Sri Lanka ten year development framework (2006-2016) and the national policy for decent work in Sri Lanka is to create opportunity for all men and women to obtain productive work in conditions of freedom, equity, security and human dignity and migration can be considered as a part of the overall agenda of the plan. In order to produce skilled labourers to the global market policy is developed in three sections namely; governance of the migration process, protection and empowerment of migrant workers and families, linking migration and development process.

Under good governance, regulating the migration process has been identified as an important point. It emphasizes the four interrelated dimensions, namely fundamental principles and rights at work, employment and incomes, social protection and social dialogue which at global level, contribute to a "fair globalization" (National Labour Migration Policy,2009: 09). Following this Sri Lanka has the regulatory system and body for the overseas migration process. Sri Lanka Bureau of Foreign Employment is the main governing body of this migration process and it has the legal mechanism to regulate the migration process which ensures the protection of migrants. It secures the decent work and the rights of employees.

National migration policy has addressed the problem of the vulnerability of migrant workers. Though it is a gender-neutral it has emphasized the women security in the process of migration. Legitimize the recruitment process is one of the important action taken in the policy. Also as literature shows a lack of skills, unskilled, the inadequacy of training and the language skill are found as the major limitations to have a secure job environment for domestic workers (Jayasundara, 2010). This too has been addressed by the policy.

\section{Deliver comprehensive training}

Sri Lanka Foreign Employment Bureau has initiated the training programme for women who wish to migrate as domestic workers. The aim is to promote skilled migrants by securing employment opportunities for skilled workers. In this training programme women were being 
trained to handle the modern kitchen appliances, they were given training for language, make aware them about the culture and religion of the host country, and whom to contact when in trouble etc. Also, it develops the language skill of those women, especially in Arabic and English. Further policy has been acknowledged the psychological conditions of the migrant workers while at their workplace. This residential training was identified as a good opportunity for them to make their mind to cope up with their emotions. Moreover, health issues associated with migrants also addressed in the policy and in the training migrants are made aware of the STDs especially HIV/AIDS. This training programme was designed as pre-departure training for Israel bound male-female caregivers, predeparture training for the Middle East bound Domestic sector female housekeepers and caregivers, predeparture training for domestic sector housekeepers and caregivers to Europe, the far East and East Asia/other countries excluding the Middle East, and awareness programme for all first-time male/female workers other than domestic housekeepers, caregivers and professionals to the Middle East. These courses are conducted every month and the frequency of the course depends on the number of registered persons. The SLBFE has realized, lack of knowledge on housekeeping and general knowledge on work away from the country are reasons why women become more vulnerable during at work and at the predeparture stage. Therefore, they have introduced these training programmes for migrant workers. Especially for the women who wish to migrate as domestic workers, they have designed a 21-day residential training programme including language training. The objective of this residential programme is to prepare them to stay away from the family and adjust to a new place, and overcome mental or emotional sicknesses. These training centres are managed at the regional level and instructors are women who previously worked as domestic workers in the Middle East. This training certificate is essential to register at the SLBFE. One of the general objectives of the SLBFE is to minimize the unskilled women labour migration, in order to prevent harassment in the host country.

Nevertheless, the policy has emphasized the age limits to migrants in specific countries i.e, for Saudi Arabia age limit has been increased up to 25 and for other Middle East countries it is 23.It has identified the age group below 23 are tend to be vulnerable, exploitation and abuse at the workplace. Government has identified that mother's caring needs for kids and it affects the family. Thus for mother of children under the age of 6 is not allowed to migrate. Age limits have been identified for different work and different countries (National Labour Migration Policy, 2009).According to the officials at 
SLBFE, these all actions were taken towards the protection of migrant workers and some are for female migrant workers. That because the policy it-self believes, that the above limitations tend to migrants workers in vulnerable situation and age is the most important factor which makes women vulnerable due to their immaturity.

However, the interviews conducted with bureaucrats at SLBFE, it was found that when conducting the training programme, bureaucrats face the problem of lacking expertise in the relevant fields. Especially in domestic work. They have not yet identified a solution to finding more professional instructors who previously worked as housemaids. "Once trainees realized that those instructors have previously worked as housemaids in Middle East countries, they do not care for them and are not serious on this." - A Manager

Furthermore, officials have stated the number of days of training is not sufficient to make skilful domestic labourer yet no solution has found. However, all these trained women are evaluated by the National Vocational Qualification (NVQ) exams. The NVQ certificate is designed according to international standards and is recognized in many countries in the world. Therefore, most street-level bureaucrats (SLB) believe that trainees with an NVQ certificate would acquire recognition irrespective of the limitations at the training centres.
During the research, it was found this training is benefited for the women who have no prior experience in domestic work for some certain extent.

\section{Regulating the recruiting system}

The role of the government is to send migrant workers through a legal channel. In this migration process, there are three stakeholders mainly involved, they are the government, local manpower agency and foreign manpower agency. There is a system to register the migrants at SLBFE, as well as local manpower agencies, must be a registered one at the SLBFE. Legalizing the recruiting agencies secure the migrant worker both at the pre-departure stage as well as in foreign soils. Migrants have to sign a service contract with the local manpower agency who act on behalf of the foreign employer and SLBFE facilitate in this process. This contract certifies the hours of work, salary to be paid by the employer and service period of the employee. If the employer breaches the contract, the government can take necessary actions against the foreign manpower agency. Also before they leave the country expects migrants should get travel insurance coverage from the company associated with the SLBFE. Not only that, those who expect to migrate need to get a medical certificate which confirms their ability to work and health. SLBFE facilitate all these services which further ensures that they send the qualified and appropriate labourers to the labour 
market. However, the main problem identified by the bureaucrats was mush rooming the agencies and their dishonest behaviour. Since the demand is high in the labour market agencies are trying to send women without waiting and they were given fraud documents of medical, training which should be acquired from the SLBFE.

"It is very difficult to handle these agency people; they are very cunning and try to get approval from lateral pathways. Avoiding the proper channels, they attempt to get approval for the job orders." A Manager

This further reveals that there is a gap in implementing the policy by bureaucrats and mediation of local manpower agencies are much more powerful. From the point of local manpower agencies, corruption in the government agencies creates a situation much easy to make illegal documents.

"In this country, making a fake birth certificate or a national identity card is simple. Once an SLBFE officer told me, a passenger's passport seemed like a fake one, so they do not want to register it. Yes it was issued on a fake birth certificate, so I explained to the officer it is not my fault, it is the fault of the immigration department, so please register my customer, as we the agency has a bond to send this lady on due time. So my job was done"-Subagent

This simply proved that the even though bureaucrats at SLBFE is much concern about the fraud documents corruption in other government agencies which hinders the legal procedure of labour migrator and as a result policy could not protect women as it is expected.

\section{Legal Support}

Despite the above process, SLBFE has a separate section which migrants or their family can make complaints against the local manpower agencies or complaints against the employer. SLBFE works as a mediator between migrant and the sending agency if the agency does not take action SLBFE can take legal action against the manpower agency according to the law and order in the country. At the same time, if the migrant cheats the manpower agency, SLBFE takes action against the migrant too.

Other than the government, the local manpower agencies play an immense role both directly and indirectly. Directly they send migrant workers to Middle East countries through the approval of the SLBFE. This restricts human trafficking. Not only that there is a provision of cancelling their licenses' if they were unable to provide safe workplaces for the workers. They are bonded with the government as well as the employee to provide the promised salary in the service contract and send the worker back to the country after the contract period. Statistics of the SLBFE (2016) shows the number of complaints made by female migrants for breach of contracts by the employee, especially not paying the promised salary and not sending them back on due time. 
Most of the complaints were settled according to the statistics of the SLBFE 2015-16 and it comprised 85\% total complaints received, however, those complaints were mainly on nonpayment of salaries, this has been solved by the local agent by paying compensation to their client. However, the records do not mention how they settle the other cases such as sexual harassment or physical harassment experienced by the migrant women. Also, there is no evidence of the time period taken to solve each problem.. If a local manpower agency was unable to solve problems the SLBFE can suspend the license of the agency and if they repeatedly do the same error after some investigation the agency will be blacklisted at the SLBFE, no more opportunities will be given for them to send employees to foreign lands for those agencies. The legal division mainly acts in order to protect migrant worker but not agencies. Nevertheless, in practice, they try to make decisions that are free and fair to both parties.

"We usually appear for the worker's party, but we know that agencies are busy and due to their busy schedule, they have done some mistakes; women also cheat agency, by taking money from the agency and not going on time, or coming back before the contract terminated. So at that time, we try to negotiate with both parties. Due to one complain, an agency may get suspended and will lose their whole business." - Legal Officer
This indicates that SLBs appear not only to protect workers but also to protect the business of their stakeholders.

Instead of the policies to protect migrant at the pre-departure and while at work, it has ensured the protection during repatriation. Insurance coverage has been introduced for workers who meet accidents, compensation in case of death incident. Migrants were aware of this insurance at the training. The policy has identified the need for reintegration the returnees and provides benefits for children in the returnee's family. However, during the field visit, it was found that protecting during repatriation was not really happened. In the focus group discussion, one was identified as injured physically due to an accident at the workplace. According to her, she was thrown down from steps and her leg was broken. She returned home with nothing and still lives in a mud house.

"When I met with an accident, my boss admitted me to the hospital. I informed my parents and they informed the agency and SLBFE, but it was useless. My parents are poor they cannot go to the agency or Colombo several times. Nobody took any action, the agency blamed on me; they said after 2 years they cannot take any responsibility, and I was in my third year. After three months, I returned with a disability, I wrote to many places, nothing happened; now I cannot do any work due 


\section{Original Article}

to the pain in my ankle." -Migrant woman

Complex legal procedures at SLBFE keep women away from the organization. Some women were asked to come several times to the office with several documents. They are fed up with that, and on the other hand, as per SLBs experience, unawareness of the system causes unnecessary delays in problemsolving.

Women and their family members face several practical issues like unawareness of the legal support given by the SLBFE. Conversely, due to those women's low socio-economic background, they are reluctant to take legal action, and they do not follow up the case after sometime. The reason was that those women and their family members do not want to bother further due to the difficulties of travelling to Colombo as it needs money and consumes time. Despite these practical problems, the SLBFE neglected some cases reasoning that the problem has been solved somehow and that's why these women or family members do not come to the SLBFE. This indicates the inefficiency of SLBs in solving problems faced by migrants and the relevant database they are maintaining is not reliable too.

THE VULNERABILITY OF WOMEN LABOUR MIGRANTS: POLICY AND PRACTICE

Based on the previous literature a question was identified as "why these women are being vulnerable and harassed in their pre-departure stage and while at their work, though the policy being implemented"?. To explore the answer, returnee migrant workers, some of the officials at the SLBFE and local manpower agencies as well as some middlemen who play a hidden role in this migration process were interviewed.

This study revealed that women were encouraged by their neighbours or relatives who previously went to the Middle East as domestic workers. And they are the main source of information which migrant women rely on. At the pre-departure stage, they were trapped by some illegal manpower agencies and irresponsible sub-agents. Those sub agents are from the same community, village or sometimes they are close relatives of women like husband, brother or some known person in the area. They announce the job vacancies by word of mouth in the community and convince women that they could migrate safely. However, those sub-agents are not officially appointed by any local manpower agencies. There is no legal bond between them.

At the current system of sending workers to the Middle East country, a local manpower agency receives a minimum of 600,000 to 800,000 SLR per person. To earn more money they encourage women to migrate through their sub-agents in rural villages. These subagents are paid 400,000 SLR for each woman that is being taken to the agency and a woman is paid 
200,000 to 300,000 SLR before she leaves the country. Actually, this money will be paid at the predeparture time, so that she can use it to settle family needs and other requirements. This will encourage more women to go to the Middle East as domestic workers and also this money is a boon for them to solve their economic problems at least for a short period of time. But the worst incident found in the fieldwork is that most of the women have not been paid this amount from the sub-agent or local manpower agency. Subagents are not bound to pay money for women. In this bargaining system, mostly husbands of the migrant woman involve with the sub-agent or women go to a reputed person who pays more before they leave. According to the sub-agents 250,000 to 300,000 SLR is paid if a woman is at young age and if she is above 50 years old 100000SLR will be paid. In this pre-departure stage, women's labour was bargained and exploited by the men dominant process. It is a pathetic situation that they were auctioned in the labour market for 200,000 SLR. However, some women were never paid this amount, either because they do not have the capacity to demand their labour or because they were unaware about the system going on and they were trapped by sub-agents. From the sub-agents' view, it was revealed that if a woman has some problems to make documents, or if she wanted to migrate just to escape from their family or husband usually this type of women were not paid.

The most vulnerable situation that women faced during the predeparture stage is men sell their sisters and wives to sub-agents to get money. Sometimes husbands of these women represent themselves as subagents to the local manpower agency and promised them to collect some women. In order to earn money from the system, they force their wives or other relatives to go to the Middle East through that particular local manpower agency. On such occasions, women never receive the money and all the money goes to the husband. This gives evidence about how patriarchal power structure controls this migration process even policy has been introduced by the government. According to the SLBFE that they do not have any provision to get involved in this as this totally happened outside to the migration process. SLBFE has maintained the registration of employers through the help of the Sri Lankan Mission in respective countries. Transferring money from foreign agency to local agency is beyond the control of the government and neither SLBFE has paid their attention to how to control this bargain system.

The study revealed that in some cases those women were sexually harassed by the sub-agents. One of the subagents met during field visit keeps a small house as a transit place for women and those women who wanted 
to go without the consent of the family/husband this subagent's house or far away from the district is a shelter for them until they migrate. These women who were keeping at subagents' hostel/house were economically exploited. They were not paid any amount prior to leaving for the job and sub-agents justified that he has to spend a lot of money for keeping her in the hostel to make documents including passport and other relevant documents.

"Why should I pay a lot of money for her? I gave her accommodation and food at my house, send her safely, they only want to go away from their family; I have to spend money to make fake documents, and give telephone calls; who will pay for this? It is a burden for me until they reached the host country."-Sub-agent

Further, it was revealed through a focus group discussion that this subagent sexually abused those women while they are at the house. Though none of the group members experienced such abuses they pointed out the incidents happened to a known woman related to particular sub-agent. The involvement of sub-agents in the migration process is very strong as they have to keep relationships with manpower agencies. Manpower agencies have close relationships with some of the bureaucrats and that leads to send women providing illegal documents. The corrupted bureaucratic system in the country gives provision to made fraud documents, like birth certificates for the woman who are not entitled to migrate, and women who do not have the training certificate of SLBFE which is mandatory for the registration and family background report. Evidence for this process has been unfolded during the interview had with the subagent.

Those sub-agents along with the local manpower agents put the women in a risk situation then, because they are sending unqualified, underage or overage women, and when they face problems at the workplace no one takes the responsibility. Though the policy is implemented for some extent the way it implemented was not protect women rights and it was identified how discretion power used by bureaucrats. According to Lipsky (1980), street-level bureaucrats categorizing the clients using their discretion power. The same pattern is visible in this migration process. They have identified women as a weak group and because they are suffering from poverty this migration is the only hope for them to overcome their problem. Bureaucrats and manpower agencies have taken the advantage of this. The most significant factor revealed in this study was those women were forced to get birth control either permanently or temporary. According to SLBs, this was advised during the training period as sending pregnant women is illegal. However real intention was unfolded during the lengthy discussions had with SLBs as this protects them to get pregnant even a 
woman gets sexually abused in the host country. This questions whether the country sends women to a risky land? Sub-agents are very keen to make false medical reports. But once they undergo the medical test in the Middle East, some has to come back immediately or face problems at the workplace. One lady returned with a 2-week old infant at "transit house" at Katunayake run by the SLBFE telling that she gave birth to the baby with a lot of pain and luckily the employer looked after her and sent her back too. During the interviews done with bureaucrats at SLBFE revealed that the famous incident of Rizana was the same illegal recruitment made by the sub-agent.

The government does not take the responsibility of the migrants who migrate in illegal procedures. So they have to suffer at safe houses or foreign employment agencies unnecessarily due to the trust they kept on subagents. One overage woman (55 years) was caught at the airport and she was kept in a prison and fined 30,000 SLR. But she said "I don't know that I was given a fraud visa, a lady (sub-agent) came to the village and asked me to get ready to go to Kuwait, since $l$ have previous experience there, I was happy on the opportunity to go. I was advised by that lady to tell the SLBFE officers at the airport that I am going to visit my daughter there. So when officers examined I said the same, but I couldn't answer further questions, at that time they caught me, luckily the lady who brought me was there and officers were able to catch her too." This proved the fact that women were being trapped into illegal trafficking, especially women suffer from bad economic issues and low literate or illiterate women are more vulnerable in this situation. Furthermore, it proved that there is a gap in the policy implementation process.

Since the sub-agents play a very important role in the process of migration still neither SLBFE nor local manpower agents were taken any steps to legalized them. SLBFE has identified that women are being in risk situation due to the involvement of these sub-agents. Even local manpower agents don't have any mechanism to registered sub-agents under their offices. However, most small scale manpower agencies have totally depended on those sub-agents and even the reputed manpower agencies are keeping subagents as women suppliers. This was identified as a high risk factor in the migration process.

These women who interviewed during the research endure all these harassments and injustice condition due to their less power and there is no other way to secure a better future for their family. Empirical data shows that most of the women migrate through the social networks that they have. Trust is the key ingredient which keeps the bond between middlemen and the employee. Women have relied on subagents and manpower agencies than SLBFE. The low income of the 
family becomes a push factor and those middlemen guaranteed the labour market for them as a solution for their hardships. However, most of the women interviewed were harassed in a different way at their predeparture stage, mainly exploiting financially or not sending the promised workplace etc. "I got only 75000 rupees prior to my departure. Since it was my first visit, subagent gave me this less amount and I have no bargaining power either." A migrant woman

"my workplace is not good for me, the boss in the house is very harsh and I had to work long hours. Then I request my agency to change the place but it didn't happen. Instead of changing the place they advised me to tolerate all the difficulties. But I couldn't tolerate and later ran away from the house and finally, I was kept in a safe house and returned home with empty hand" - A migrant woman

Furthermore, women were in risk situation due to keeping trust on those networks than the government registered agencies. Lack of education and unawareness of the migration procedure cause severe problems before departure as well as while at the workplace. However, knowing that they were financially exploited by those subagents, still, women believing the next sub-agent whom they meet will be honest than the previous, and waiting to find an honest sub-agent rather going to the local manpower agent directly. Based on the research data, it revealed that sub agents are playing a hidden role in the process of migration and it makes women more vulnerable. Moreover, this reveals that service given by the SLBFE is not sufficient or they have some limitation. Though the SLBFE has conduct awareness programmes, women do not directly go to them. Also, officials at SLBFE do not have any interest to make aware people through media as it is costly, and they disclosed that the awareness programme also not a success. Still, SLBFE is not able to win the trust of these migrant workers.

Not at the pre-departure stage, even at the workplace women migrants workers were exploited and abused especially the domestic workers who confined to the employer's home in the host country. They were at high risk due to the law and custom of Middle East countries. Most of the women were not allowed to come out from the house alone and in some incidents, it was reported they were not allowed to get phone calls. These women were bound to work in one place at least for the first 3 months until the foreign agent consider changing the workplace. As a result of the restriction of changing place some women had to run away from the house and some cases were reported committed suicide for not being able to tolerate the harassments. Some were kidnapped, raped while they were going along streets and as a result, they were kept in the police, and safe houses under the Sri Lankan High Commission in respective countries. Due to fewer health facilities in these 
safe houses, these displaced women tended to get communal diseases such as flu, cold and embassy give less attention to them. When they were imprisoned embassy has to appear for the citizen of the country. However, according to SLBFE, it is a limitation as they do not have good translators. This was identified by a consular in Saudi Arabia in the death case of Rizana (Inamullah, 2012).

The patriarchal ideology of street-level bureaucrats justifies that National Labour Migration Policy regulating the migration process. According to SLBs women make deceptive complaints when they want to come back home. However study revealed that SLBFE mainly involved in solving the problems of nonpayment of salary, changing the workplace if the migrant worker faces any difficulties. Role of SLBFE is to mediate local manpower agency and the migrant. If the migrant worker is not being paid local manpower agency has to pay the salary and on the request of changing place they have to change the place. However, in practice-changing place takes 3 months. Officials at SLBFE were very much concern about the right and benefits of local manpower agent in this regard. Most of the officials were trying to justify that changing the workplace is not as easy as both local and foreign employment agent was paid by the employer in the host country. SLBFE were more sensitive to those stakeholders than migrant workers. Moreover, attitude towards women migrant workers is negative among officials in SLBFE. These domestic workers were identified as low educated, less power and cunning people by the SLBFE. This perception towards women domestic workers limits to make fair decisions taken by bureaucrats. Moreover, due to this negative attitude bureaucrats were not encouraged to get involve the problems of these women migrants seriously. Hence when women migrants face difficulties during pre-departure and during in host country they were discouraged to make complaints. This resulted find their own way to escape and ultimately they were in a risk situation.

It was clear through the policy aims to protect migrant workers, in practice, it is not really happening. According to women migrants training which given to them has little impact to protect themselves however yet to be improved. Many officials at SLBFE agreed that the training is not sufficient and not up to the standards.

\section{Role of street-level bureaucrats in policy implementation}

The bottom-up approach of policy implementation is emphasized in street-level bureaucrats' behaviour, and according to Lipsky (1980), discretionary power explains policy change and reshaping. They believe street-level bureaucrats know well the system of achieving policy through reshaping the policy. Along with Lipsky (1980), Elmore (1979), Sabatier (1975), Matland (1995), and Winter 
(2002) agree that it is important to study the behaviour of policy implementers at the discourse of policy effectiveness in the synthesis approach. Winter elaborated the model which explains policy performance, and explained variables that influence policy performance. Following Winter's model, this study borrowed the street-level bureaucrats' behaviour and finally reshaped the independent variable of this study as the role of street-level bureaucrats.

The study identified a number of explanatory variables that influence the role of bureaucrats (independent variable) in policy implementation such as, clarity of goals, the motivation of street-level bureaucrats, and attitude of bureaucrats. These variables may be similar to every country though the effect may differ country wise. Therefore, analysis of these independent variables and dependent variable (goal attainment) in a specific country context is more useful to enhance the knowledge of policy implementation.

The study revealed that they have no intention of reaching the goals of the organization as they were not aware of the policy goals. However, StreetLevel Bureaucrats'(SLB) role is ruleoriented; they are only aware of the rules and laws but not the meaning behind those rules. Their understanding of policy goals constrains their capacity to reach the policy goal. Their intention is just merely to implement the law and they use their discretion power where they needed. Above discussion explained their business with the women target group. Since they were more concern about filling the vacancies in the labour market, they just ignored the right of women and their protection. Therefore it is evident that the clarity of goals, how bureaucrats clarify the goals and their understanding, have a strong relationship between the role of bureaucrats and effective policy implementation.

Gollwitzer and Sheeran (2006) explain the importance of the implementation intention in successful goal achievement. The concept of implementation intention is valuable both in understanding the processes of goal attainment and in providing a self-regulatory strategy to help people to reach their goals. Furthermore, Lipsky (1980) explains the worker alienation and how it may lead to dissatisfaction, and as Tummer (2011) explains, the policy alienation leads to low performance of SLBs. Corruption and political intervention are highly significant and that demotivate SLBs from continuing their work, and they felt as if their work is meaningless as politicians meddle in decision making. Therefore, they do not really follow the policy goals to protect migrant workers. As the bureaucrats are not sufficiently motivated, their commitment to performing the relevant role is limited, which may even lead to non-implementation. 
Saltzstein (1979) cited in Riccucci \& Mayers (2004) presented a model which links the social origins, values/beliefs/attitudes, actions, and policy outcomes. This study focused on gender characteristic of SLBs (social origin) and their belief on their clients and social policy (values). Focusing on these values and social origins this study follows the Saltzstein model of active and passive representation. Since the majority of the SLBs are males and their attitudes towards women are more patriarchal. As explained above they do not pay much attention to women's issue as they believe that these women are cunning and not having good discipline. They were in favour of recruitment agencies rather than these target groups. Their negative attitude mind setups analyse the domestic worker problems in the host country as a problem of woman character only. So they keep advice to a woman makes policies to control them. This proves that the attitude of bureaucrats of SLBFE also hinders the rights of migrant women and these limits to reach the policy to its objectives.

In this patriarchal structure, women were not given to the attention of the government in empowering them. Government policy is to empower migrants once they returned by helping them financially to start their own business. However, this was not practising for the women migrants and reason which SLBFE given was lack of savings with these migrants. This proved that women were neglected in the process of empowerment, and they were still vulnerable in the migration process. Though women's gender role has been transformed from reproductive to productive, this transformation does not have the capacity to change the traditional gender ideologies entrenched in society. Further government policy itself constructs gender inequality rather reducing the gap and still these women remain as second sex though they are the partners of income of the family.

\section{CONCLUSIONS}

This study focused on one major goal of the National Migration Policy in Sri Lanka, i.e., protection of migrant workers. To measure the policy goals achievement, three measures are employed, namely, (i) delivering comprehensive training and dissemination of information, (ii) strengthening the laws, and (iii) monitoring and minimising abuses, as explained in the policy document. The empirical evidence was obtained from interviews held with SLBs, women migrants, and recruitment agencies

As a country, we earn a US\$ billion 6.4 of foreign exchange through labour migration and mostly covered by the domestic workers in the Middle East. Women who come from a rural area with low education were attracted to this labour market. The main driving force to migrate as a domestic worker is to achieve economic stability. Their main expectation is to buy land and build a house and educate children. 
Most of the studies reveal the problems faced by these women at their workplace and how women were being exploited before they leave the country. Nonpayment of money, cheating them, forcing, directly and indirectly, to go for domestic work, sexually abused by the sub-agents were more prevalent blazing issues. In this study reveals that women became more vulnerable due to the involvement of these middle man. Though these issues were acknowledged in the policy, when it comes to implementation it was largely ignored by the respective authorities. This happens mainly because of the power imbalance among men and women in the country as well as in the policymaking and implementation organizations. Furthermore, street-level bureaucrats were demotivated and pay less commitment due to the political intervention at the organization. Low understanding of policy goals leads to policy implementation unsuccessful. Most significantly negative attitudes towards domestic workers demotivate bureaucrats at SLBFE to implement the policy to reach its goals. Moreover, the National Labour Migration Policy enriched with the ideology of gender equality but when it comes to domestic workers, it discriminates the rights of migrant women.Further, she was bound to the traditional female role in the country. Policy action taken irrespectively to the needs and the condition of the women, the policy may not successfully achieve its goals.
Therefore the government needs its focus on to control this migration process and bring back the migrants in line with the legal procedures. Low knowledge of policy goals, less motivation and less commitment and negative attitude of street-level bureaucrats resulted in the policy implementation unsuccessful. Research on Sri Lankan labour migration has not sufficiently explored how far the street-level bureaucrats play their role in order to achieve the policy goal and which factors hinder the successful policy implementation. Hence this study contributes the literature on policy studies in Sri Lanka and this opens up some avenues for future research on migration as well as policy implementation studies.

\section{References}

Abeyrathne, U. (2013). Participatory Development and Beneficiary Implementer Syndromes: A Study on National Poverty Alleviation Programme in Sri Lanka, Social Sciences and Humanities Review,1(01), 156-186

Gollwitzer, P. M., \& Sheeran, P. (2006). Implementation Intentions and Goal Achievement: A Meta-analysis of Effects and Processes. Advances in Experimental Social Psychology, 38(6), 69-119. Retrieved from https://doi.org/10.1016/S00652601(06)38002-1

Hettiarachchi, S. (2007) Violation of Women Rights in the Middle East .International Journal of Arts and Commerce [Online] Available from <http://www.ijac.org.uk $>$ [Accessed on 23 ${ }^{\text {rd }}$ May 2014]

Hettige, S.T (1997) Social Cost of Migration Document from the International 
Conference on Migration Women Workers. Colombo, The American Centre for International labor Solidarity

Hettige, S.T (2012) Understanding psychosocial issues faces by migrant workers and their families. The Swiss Agency for Development and Cooperation

Hill. M \& Hupe.P (2014). Implementing Public Policy (3rd ed.). London:Sage

Howlett, M., Perl, A. \& Ramesh, M. (2009).Studying Public Policy (3 ${ }^{\text {rd }}$ Ed.). Oxford University Press, Canada

Hupe, P., Tummers, L., \& Bekkers, V. J. J. M. (2012). Discretion and Its Effects: Analyzing the experiences of street-level bureaucrats during policy implementation. EGPA Conference. $<$ http://repub.eur.nl/pub/34726/>

Inamullah, M (2012). Lessons Learned from Rizana Nafeek's Death Sentence. Retrieved from $<$ www.almuslimath.com>

Jagger, Alison (1983) Feminist Politics and Human Nature. NJ Rowman \& Allanheld

Jain, R. (1987). The Role of Bureaucracy in Policy Development and Implementation in India. Southeast Asian Journal of Social Sciences, 15 (02). < http://www.jstor.org/stable/24491120 >

Jayasuriya, Laksiri (2000) Welfarism and Politics in Sri Lanka, Experience of a Third World Welfare State. Perth: University of Western Australia.

Kottegoda, S (2006) Bringing home the money: Migration and Poverty in Gender Politics in Sri Lanka in Gender and Migration. New Delhi:Sage

Lipsky, M (1980). Street Level Bureaucracy: Dilemmas of the Individual in Public Services' Sage Foundation: New York

Mahanama, C \& Thennakoon, T.M.S.P.K. (2012). Problems of migrants workers in the Middle East : A case study of return female migrants. International Conference on Humanities and Social Sciences. Retrieved from http://journals.sjp.ac.lk/index.php/IRCH S/article/view/2346
Matland, R. E. (1995). Synthesizing the Implementation Literature: The Ambiguity-Conflict Model of Policy Implementation. Journal of Public Administration Research and Theory, 5(1986), 145-174. Retrieved from https://doi.org/10.1093/oxfordjournals.jp art.a037242

May, P. J., \& Winter, S. C. (2007). Politicians, Managers, and Street-Level Bureaucrats: Influences on policy implementation. Journal of Public Administration Research and Theory, 19(3), 453-476.Retreived from https://doi.org/10.1093/jopart/mum030

Mazmanian, D \& Sabatier, P. (1983).Implementation and Public Policy.:Foresman and Company:USA

National Labour Migration Policy for Sri Lanka. (2008), Ministry of Foreign Employment Promotion and Welfare: Colombo

Navaratna-Bandara, A. (2013). History and Context in Public Administration in Sri Lanka In Sabharwal, L \& Berman, E.(Eds.), Public Administration in South Asia. CRC Press: New York

Pinnawala, M.(2009). Gender Transformation and Female Migration: Sri Lankan domestic workers negotiate transnational household relations. Shaker Publishing: New Delhi

Pinnawala, S (1997) Protecting the Goose and the Golden Eggs: Sri Lanka's Policies on Her Overseas Contract Workers, Essay In History and Sociology: in Honour of Professor W.M.Sirisena. Kandy, University of Peradeniya

Riccucci, N. M., \& Meyers, M. K. (2004.). Linking Passive and Active Representation: The Case of Frontline Workers in Welfare Agencies, 14(4), 585-597. Retrieved from https://doi.org/10.1093/jopart/muh038 Accessed on 04-04-2016

Sabatier, P. A.(1986). Top-Down and BottomUp Approaches to Implementation Research: a Critical Analysis and Suggested Synthesis. Journal of Public Policy, 6(1), 21. Cambridge University 


\section{Original Article}

ISSN: 2279-3933

Press<http://www.jstor.org/stable/39983 $54>$

Sabatier, P and Mazmanian, D.(1980). Implementation of Public Policy: A Framework of Analysis. Policy Studies Journal, 8(4) 538-559

Sri Lanka Bureau of Foreign Employment (2017). Annual Statistical Report of Foreign Employment. Colombo.

Transparency International. (2010). $A n$ Integrity in Foreign Employment: An analysis of corruption risks in recruitment, Transparency International: Sri Lanka

Tummers, L (2011). Explaining the willingness of public professionals to implement new policies: a policy alienation framework. International Review of Administrative Sciences, $\quad 77(3), 555-$ 581.Retreivedfrom https://doi.org/10.1177/002085231140736 4

Ukwatta, S (2010) Economic and Social Impacts of the Migration of Sri Lankan Transnational Domestic workers on families and Children Left Behind. PhD Thesis, University of Adelaide

Van Meter, D. S., \& Van Horn, C. E. (1975). The Policy Implementation Process: A
Conceptual Frame Work, Administration $\mathcal{E}$ Society, 6(4), retrieved from $<$ https://doi.org/10.1177/00953997750060 $\underline{0404>}$

Warnapala, W. (1974). Civil Service Administration in Ceylon: A Study in Bureaucratic Adaptation. Dept. of Cultural Affairs: Sri Lanka

Wickramasekra, Piyasiri (2013) Globalization, International Migration and Development: Rhetoric and Reality, Key Note Address presented at An International Conference on Migration, Colombo: National Science Foundation

Winter, S.C (2002). Explaining bureaucratic behaviour in social and regulatory policies. Paper prepared for the 2002 Annual Meeting of the American Political Science Association in Boston, 29 August 1 September 2002

Winter, S.C. (2013). Implementation Perspectives: Status and Reconsideration, in Peters. G. \& Pierre J. (Eds), The handbook of Public Administration. London: Sage 